Article

\title{
Agricultural Climate Change Adaptation in Kebumen, Central Java, Indonesia
}

\author{
Andung Bayu Sekaranom ${ }^{1,2, *}$, Emilya Nurjani ${ }^{1}$ and Fitria Nucifera ${ }^{3}(\mathbb{C}$ \\ 1 Department of Environmental Geography, Faculty of Geography, Universitas Gadjah Mada, \\ Yogyakarta 55281, Indonesia; emilya.nurjani@ugm.ac.id \\ 2 Research Center of Disaster Universitas Gadjah Mada, Yogyakarta 55281, Indonesia \\ 3 Department of Geography, Faculty of Science and Technology, Universitas Amikom, \\ Yogyakarta 55283, Indonesia; fnucifera@amikom.ac.id \\ * Correspondence: andungbayu@geo.ugm.ac.id; Tel.: +62-274-6492340
}

Citation: Sekaranom, A.B.; Nurjani, E.; Nucifera, F. Agricultural Climate Change Adaptation in Kebumen, Central Java, Indonesia. Sustainability 2021, 13, 7069. https://doi.org/ $10.3390 /$ su13137069

Academic Editor: Piotr Prus

Received: 19 May 2021

Accepted: 20 June 2021

Published: 23 June 2021

Publisher's Note: MDPI stays neutral with regard to jurisdictional claims in published maps and institutional affiliations.

Copyright: (c) 2021 by the authors. Licensee MDPI, Basel, Switzerland. This article is an open access article distributed under the terms and conditions of the Creative Commons Attribution (CC BY) license (https:/ / creativecommons.org/licenses/by/ $4.0 /)$.

\begin{abstract}
Productive agricultural areas in Kebumen, Central Java, Indonesia are potentially vulnerable to the adverse impacts of climate change. We surveyed small-scale farmers to assess climate change-related perceptions and adaptations in the agriculture sector. The majority of the respondents agreed that there were changes in climatological variables affecting their farming activities, especially in terms of precipitation and temperature. However, the results also revealed that only $13 \%$ of respondents believed that human activities play a significant role. Three forms of adaptations have been developed by the farmers, namely: (1) agricultural diversification, (2) agricultural intensification, and (3) socioeconomic adaptation. Changing crops to more climate-tolerant varieties was one of the most common agricultural diversification practices (implemented by $88 \%$ of farmers). Most of the farmers also tried to maintain agricultural productivity by adjusting a local planting calendar (implemented by $94 \%$ of farmers). The use of machinery to intensify farming practice was an uncommon strategy (implemented by only $30 \%$ of farmers) because of expensive maintenance and small cultivation areas. The results suggested the importance of increasing farmers' knowledge and technological know-how related to climate change and its implications, developing effective adaptation and mitigation efforts, and constructing climate-resilient infrastructure in the agricultural sector.
\end{abstract}

Keywords: adaptation strategies; agriculture sector; climate change; farmers' responses

\section{Introduction}

Since the publication of the Third Assessment Report of the Intergovernmental Panel on Climate Change, concern has been shown about the vulnerability of developing countries to the effects of climate change [1]. In Asia, Indonesia is predicted to suffer the most from the negative impacts of climate change, potentially generating major losses for economic sectors, government infrastructure, and community livelihoods [2,3]. Several potential areas for damage and loss have been identified over the entire region, for instance, from sea level rise and greater coastal flooding [4,5]. It has also been shown that climate change impacts tend to be multi-sectoral and distinct between Indonesia's urban areas and the rural areas. The urban areas, dominated by built-up environments, will mainly experience damage and losses in the economic sector, such as business areas and dense urban environments. Over the rural areas, the major source of damage and losses will come from agriculture and aquaculture [6].

The agriculture sector is vulnerable to climate change since climate change affects meteorological factors determining plant growth [7]. These factors are crucial for the Indonesian agriculture sector, which consists mainly of paddy fields that produce rice as the staple food [8]. Rice needs a high volume of water to achieve optimum growth, thus, it is highly influenced by climate variability [9]. The adverse impacts of climate change could emerge from a decrease in precipitation and an increase in temperature. As a result, 
both factors contribute to lower initial water supplies and greater losses of water through evapotranspiration. In such conditions, the water budget will continuously decrease over time and the paddy fields will become unsuitable for supporting plant growth. It has been predicted that climate change may affect short-term and long-term climate variances $[10,11]$. As a result, there may be a longer dry season or rainy season, which will lead to devastating crop failures owing to severe droughts in the dry season. In the rainy season, an increase in flood magnitudes and frequencies is expected [12]. Climate change is also expected to affect seasonal shift over the region and often produces delayed season onset [13]. Farmers often use a specific date to determine the start of the planting season. A shift in the beginning of the rainy season or the dry season, when compared with customary planting dates, could generate difficulties in determining when to plant.

Studies related to climate change impacts on agriculture have attracted much research across the world, including in North American, Asian, and African countries. In the United States, a substantial decrease in crop production is projected to occur in the south [14], owing to lower water supply and increasing evapotranspiration. In South Asia, the effects of climate change on the increasing magnitude and frequency of floods and droughts will interfere with food production in the long term despite higher water availability and proper farm management [15]. This result is comparable with sub-Saharan African countries, which are postulated to be widely exposed to the adverse impacts of climate change. Over this region, climate change has a significant influence on declining arable land and suitable agricultural areas [16].

The world population is predicted to increase from around 7.7 billion people in 2019 to 9.7 billion in 2050 [17]. Globally, agricultural production is also expected to increase by up to $110 \%$ compared to the present. However, population growth and agricultural production may vary regionally. Apart from Africa, the most significant population growth is predicted to occur in Southeast Asia, where the growth rate could reach $2.5 \%$ by 2050 [18]. On the other hand, changes in climate variability in some of these areas currently have reduced agricultural production and are predicted to continue to decline in the future. Problems of food security and hunger will potentially break out due to the combination of the two factors above. In addition, the Southeast Asian region is the region that is most vulnerable to climate change due to high climate risk and low socio-economic capacity [19]. The livelihood structures of low-income communities in Southeast Asia, which are dominated by farmers, will potentially be severely affected. The projected cost of climate change in 2050 is predicted to reach USD 14.8 billion, of which $53 \%$ comes from the agricultural sector [20]. Poverty due to climate change also has the potential to emerge in the future. Therefore, the loss of farmers' livelihoods due to climate change is a central issue to address.

Despite the abundance of scientific research addressing the impact of climate change in the agriculture sector, only a small number of studies have been conducted to identify farmers' perceptions and adaptation measures in facing the effects of climate change. Two studies in African countries, Ghana and Ethiopia [21,22], suggested that small-scale farmers had little concern about the impact of climate change, and limited adaptation options open to them. Small-scale farmers often have a lack of education, limited climate information, and also have difficulty in accessing credit and other agricultural services compared with large-scale commercial farmers $[23,24]$. These two studies highlighted that small-scale farmers have a greater exposure to climate change since they are often positioned at the lower level of social strata, where they face greater challenges in anticipating the impacts of climate change. Therefore, it is essential to understand how farmers' perceive changing climatological variables as a threat to the productivity of their farm. It is also useful to observe what kind of adaptations have already been taken up by local farmers as an input for stakeholders, so they can scale up these types of adaptations as well as facilitate better adaptation measures. Bottom-up climate change adaptations at the local level (farm scale in particular) are very important in order to adapt to increasing climate variability as well as to anticipate the predicted damage from climate change. 
Adaptation, or the ability of people or communities to respond and adjust to the change in specific climate variables, is now acknowledged as one of the most important factors in successfully anticipating climate change impacts [1,25]. In developing countries, most of the adaptation measures are not in the form of a top-down approach, but based on local community experiences without the involvement of local government [2]. Adaptation measures by farmers result from a long learning process involving personal experiences, knowledge, resources, and capacities [22,26]. It is common to categorize agricultural adaptations into two types of practices [21]. The first is agricultural diversification, where farmers select several different plants or plant varieties that are more tolerant toward water stress, which will increase with climate change. This strategy attempts to maintain a continuous, small profit by giving minimum assured returns since each crop type has a different sensitivity to climate fluctuation. Crop diversification thus can reduce the risk of a complete loss due to crop failures compared with planting only one type of crop over the entire farm area [27]. The second practice is agricultural intensification, which focuses on maintaining crop productivity by improving water and crop management practices [28]. Agricultural intensification aims to fulfill all plant needs to obtain optimum growth, for example, by building irrigation channels, maintaining water availability that is sufficient for demand, implementing soil conservation efforts, or using advanced agricultural machinery.

Java Island contributes to about $60 \%$ of the Indonesian rice production. Unfortunately, at present, a large number of productive agriculture areas have been converted to settlements and other built-up areas. This land-use conversion has been unavoidable because about $60 \%$ of Indonesia's population lives on Java [8]. Further, recent studies have indicated that the projected climate change impacts over Java may lead to more severe droughts in the dry season, and higher flood magnitudes in the rainy season [13]. By 2050, the rice production on Java is estimated to decrease about $30 \%$ of current production due to climate change [29]. This suggests that the agriculture sector requires urgent plans and actions for agricultural mitigation and adaptation. Local farmers have a limited financial capacity to respond to and cope with the adverse impacts of climate change. This makes a large contribution to Indonesia's national vulnerability to climate change [25]. More specifically, climate change and its accompanying risks are expected to have serious consequences for the national agriculture sector.

The Kebumen area, located in the central part of the island of Java, was selected as the study area location (Figure 1). Kebumen is one of the main areas for rice production in Java and is predicted to be strongly affected by hydrometeorological extremes such as droughts and floods. Despite the abundance of research related to agricultural responses and adaptations due to the changing climate at the global scale, few attempts have been made to examine farmers' perceptions and responses in this region. It should be noted that the area has a vital role in food production at regional and national levels, so largescale crop failures would have a strong possibility of disrupting national food production. Therefore, it is important to identify farmers' perceptions and responses as local knowledge acquired through long-term experience in working on their farmland can be a valuable input to stakeholder discussions on frameworks for policy formulation. More specifically, the objectives of this research addressed the following questions: (1) What are rural farmers perceptions regarding changes in the climate and what impacts have they already perceived as the adverse consequences of climate change and climate variability? (2) What kind of adaptation efforts have they already undertaken and what factors affect their choice of adaptation? 


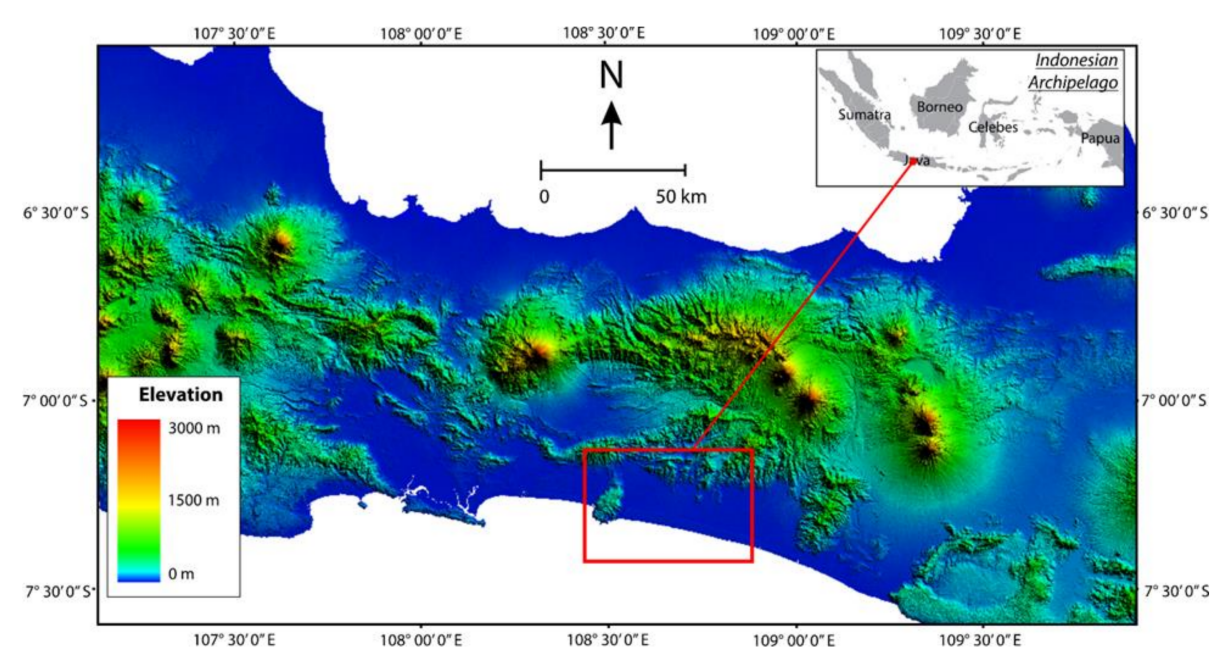

Figure 1. Geographic location of the study area (shown in red bounding box). Elevation data from SRTM.

\section{Materials and Methods}

Kebumen is one of most productive agricultural areas in the central part of Java, Indonesia. It extends from the coastal area bordering the Indian Ocean in the south to the mountainous areas of Java in the north. Most of the area consists of lowlands, with an elevation between $0-300 \mathrm{~m}$. The area is located between $7^{\circ} 27^{\prime}-7^{\circ} 50^{\prime} \mathrm{S}$ and $109^{\circ} 22^{\prime}-109^{\circ} 50^{\prime} \mathrm{E}$, with an area of 128,111 ha. Agricultural production is the main sector in this area and about $53 \%$ of the area $(94,886.5 \mathrm{ha})$ is used for agricultural purposes, broken into $31 \%$ wetland farming and $22 \%$ dryland farming. The remainder $(0.9 \%)$ is used for orchards. Settlements form about $20 \%$ of the total land use, followed by forest areas that comprise about $15 \%$ of the total area [30]. Detailed land use within the study area is shown in Table 1.

Table 1. Land use in the study area.

\begin{tabular}{ccc}
\hline Land Use & Area (Hectares) & Percentage (\%) \\
\hline Wet land farming & $39,748.0$ & 31.03 \\
Dry land farming & $28,374.0$ & 22.15 \\
Orchard & 1159.0 & 0.90 \\
Forest & $19,872.0$ & 15.51 \\
Pasture & 33.0 & 0.03 \\
Ponds and lakes & 89.5 & 0.07 \\
Settlement & $26,021.0$ & 20.31 \\
Others & $12,815.0$ & 10.00 \\
\hline Total & $128,111.5$ & 100.00 \\
\hline
\end{tabular}

Source: BPS Kebumen, 2013.

Owing to its lowland position, hydrometeorological hazards in the forms of droughts and floods are common in the study area [31]. Preliminary interviews with farmers indicated that they have experienced several natural disasters. For example, in 2005, a large drought occurred and generated crop failures over about 10,000 ha of wetland farming areas. In 2008, another large drought occurred, reducing river discharges by about 50\%. This drought affected several major rivers that are used for irrigation, including the Luk Ulo River, the Kalibanda River, and the Telomoyo River. This event not only generated a clean water scarcity for household usage, but also caused crop failures in about 1000 ha of paddy fields. Changes in climate variability were believed to be the main cause of these disasters. Moreover, this condition is predicted to worsen in the future [13,29].

To identify climate characteristics in the study area and how they have changed from the past to the present, we used observational climate data, mainly for temperature and 
precipitation, from the Indonesian Bureau of Meteorology (BMKG) from 1961 to 2010. These data were compared with the farmers' perceptions on changes to climate. The results of rainfall data processing are shown in Figure 2. These results illustrated the rainfall pattern difference between 1961-1985 and 1986-2010. Figure 2a shows changes in monthly rainfall where the peak of the dry season is in August and the peak of the rainy season is in December. Monthly rainfall tended to be lower in almost all months in 1986-2010 compared to the period 1961-1985. Figure $2 \mathrm{~b}$ shows rainfall calculated from the number of days from 1 September to the first day where rainfall was higher than $10 \mathrm{~mm} /$ day. In 1961-1985, the onset of the rainy season mainly occurred up to 15 days into early September. In 1986-2010, the onset mainly occurred about two months (61-75 days) after the beginning of September. However, the frequency distribution shows that the rainy season onset for the 1961-1985 period could reach more than 90 days, comparable to the 1986-2010 period. Figure $2 \mathrm{c}$ shows the annual dry period calculated from the number of consecutive days when rainfall was less than $10 \mathrm{~mm} /$ day. There was no significant difference between the two periods, where the longest dry period could reach more than 200 days in 1961-1985. Similar to the rainfall onset, it is likely that the data show high variability due to the influence of El Nino and La Nina. Figure 2d shows that extreme rainfall has increased in frequency, where several years of rainfall exceeded $60 \mathrm{~mm} /$ day. The above results indicate that the study location is possibly experiencing a decrease in rainfall and an increase in the variability of the onset, particularly in terms of the delayed rainy season. In the future, it is a possibility that drought and crop failure will increase. On the other hand, although the monthly rainfall is predicted to decrease, extreme rainfall will increase and potentially cause flooding.
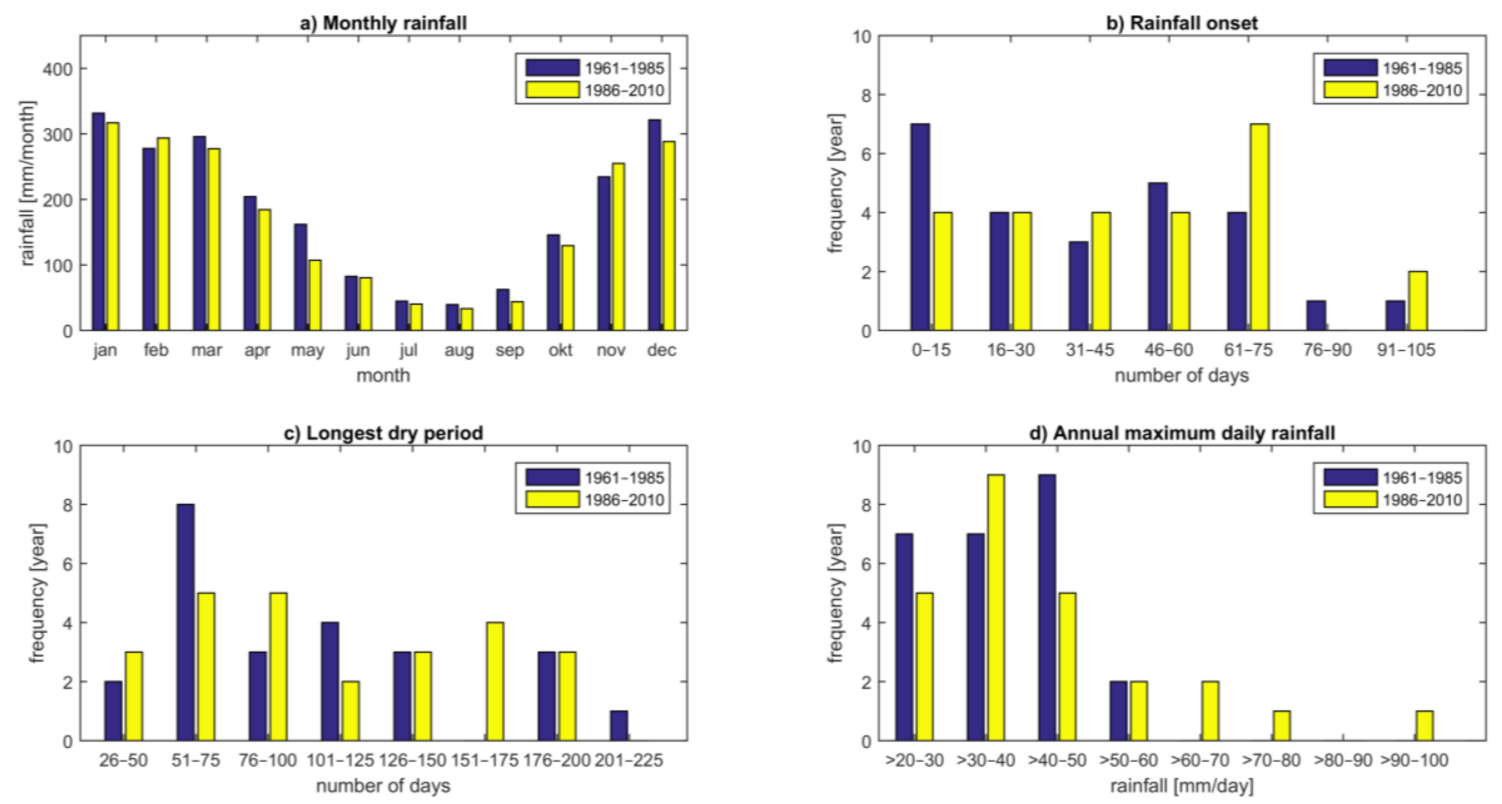

Figure 2. Comparison of (a) monthly rainfall, (b) rainfall onset, (c) annual longest dry period, and (d) annual maximum daily rainfall between 1961-1985 and 1986-2010 (data from BMKG 2014).

Figure 3 shows a comparison of the frequency distribution of (a) annual maximum temperature, (b) annual maximum consecutive days with temperature above the 90th percentile (around $27.2^{\circ}$ Celsius), (c) Thornthwaite and Mather water balance, and (d) aridity index between 1961-1985 and 1986-2010. The annual maximum temperature frequency distribution shows no significant difference between the period 1961-1985 and 1986-2010. However, the annual maximum consecutive days with temperature above the 90th percentile (as an indicator of extreme temperature) shows that the 1986-2010 period had prolonged extreme temperatures reaching 11-25 days. Meanwhile, the extreme 
temperature was less or equal to 10 days in the period 1961-1985. To further study the impact of rainfall and temperature, Thornthwaite and Mather water balance [32] and aridity index analyses were carried out. Thornthwaite and Mather water balance analysis results show a decrease in the surplus in the rainy season and an increase in the deficit in the dry season. The surplus of water in May for the period 1961-1985 turned into a deficit in 1986-2010. The value of the aridity index is obtained from the ratio between rainfall (P) divided by potential evapotranspiration (PET) [33]. An aridity index value of less than one generally indicates a soil moisture deficit. The increase in the deficit mainly occurred in May and October 1986-2010 compared to 1961-1985. The above results indicate that although the long-term average temperature trend is not very significant (an increase in the average annual temperature of about $0.025^{\circ}$ Celsius over 40 years), there was an increase in daily variability, particularly in the form of prolonged warmer temperatures. The combination of changes in temperature and rainfall is predicted to cause a higher water resource deficit in the future.
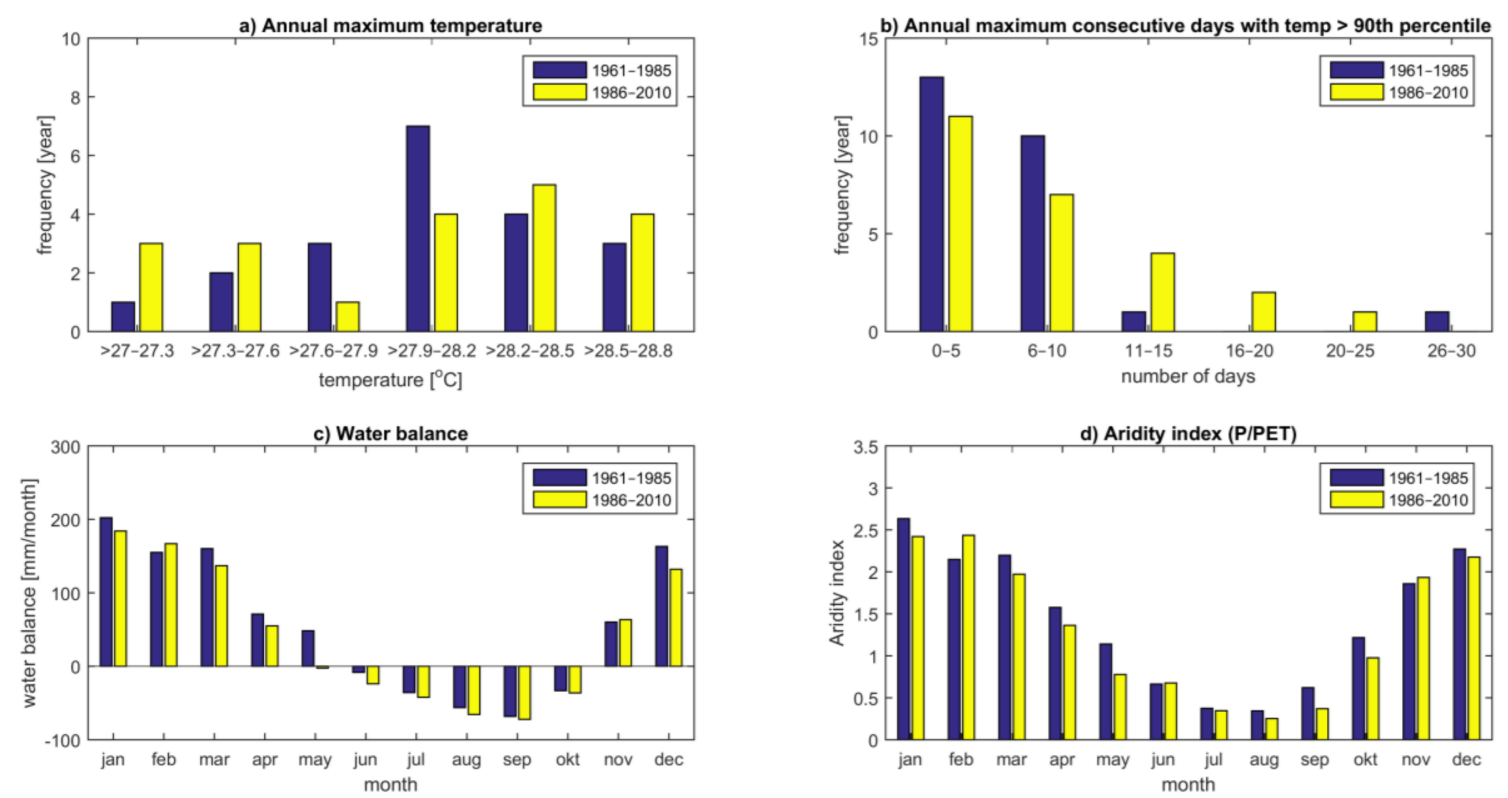

Figure 3. Comparison of (a) annual maximum temperature, (b) annual maximum consecutive days with temperature above the 90th percentile, (c) Thornthwaite and Mather water balance, and (d) annual maximum daily rainfall between 1961-1985 and 1986-2010 (data from BMKG 2014).

This paper used a qualitative method to gather primary data from a number of smallscale farmers in Kebumen, Central Java, Indonesia in September 2014. A field survey and interview-based questionnaire were used to obtain information from respondents spread over the study area. The respondents were the head of household of each family, where the main income came from farming activities. A simple random sampling method was used to select 152 respondents from the total population. This sampling method was chosen because of the homogeneous characteristics of the farmers. First, it is common that the farmers are small-scale farmers (owning less than $10 \mathrm{ha}$ ) and produce similar staple products, such as rice, corn, and cassava. Second, all of the respondents were men because farming is associated with family business. In this study, the head of household was the decision-maker for land cultivation and other family members assisted the head of household (although a small number worked in other sectors to earn additional income). In addition, most of the activities on agricultural land are carried out by men, for example, plowing, irrigating, and harvesting the fields. Male farmers are directly involved in activities on agricultural land, while women do light work that does not require much physical strength. The women's activities are often not directly involved with agricultural land, for example, seeding, drying rice, and selling crops. 
During the interview process, we delivered questionnaires consisting of several questions related to socio-demographic characteristics, perceptions about climate change, and current adaptation measures. The questionnaire was constructed on the assumption that the maximization of expected gain from their cultivation is a key factor in determining farmers' decisions in relation to adaptation efforts. In this case, the farmers will choose the most effective adaptation strategies both economically and in terms of effort while maintaining a similar profit level as if there were no adverse impacts from climate change [34,35].

To identify the perspectives and adaptation measures related to climate change impacts on agriculture in the study area, we started the process by identifying farmers' characteristics and socio-demographic conditions. By understanding these variables, we could obtain a better understanding of the background to preferred adaptation practices. In addition to general information such as age, education, and income, we inquired about the type of cultivated area in several questions, namely wetland farming, dryland farming, and orchard areas. We further asked whether the farmland was irrigated or rain-fed, as well as the main crop pattern management that was implemented by farmers.

The study covered a wide area with different topographic features, from hilly areas in the north to coastal areas in the south, so we wanted to observe whether perceptions of climate change and climate variability varied according to each respondent's experience. We asked respondents about the changes in rainfall and temperature based on their long-term observations when cultivating their farmland. Four possible answers were available: (1) I believe that there was an increase of rainfall/temperature; (2) I believe that there was no change of rainfall/temperature; (3) I believe that there was a decrease of rainfall/temperature; and (4) I am not sure whether the rainfall/temperature was increasing or decreasing. We also asked about the changes in climate characteristics on each respondent's farmland by giving two optional statements: (1) it has become very hard to predict the beginning of planting season since rain comes less regularly than used to; and (2) there are no differences in the climate characteristics at my farmland. We inquired about changes related to the beginning of the rainy season and its duration. The respondents were given a choice about whether the onset of the rainy season had changed in terms of: (1) it became delayed; (2) it became earlier; (3) it became more erratic (sometimes came earlier, but delayed in the other times); (4) there was no change; or (5) not sure about the changes. Similar choices were given for the duration of the rainy season.

We divided the types of adaptation into three forms, consisting of agricultural diversification, agricultural intensification, and socio-economic adaptation. Farmers in the study area were asked about these types of adaptation in the form of "yes-no" questions. The content of agricultural diversification questions mainly related to the selection of plant varieties by the farmers. For example, we wanted to identify whether farmers had replaced previous crop varieties with different crop varieties that were more resistant to current climate conditions, or even whether they had replaced the crop types with entirely different crops to maintain their productivity. Moreover, we tried to reveal whether the farmers cultivated different crops in a year, and more specifically, cultivated different crops within a single planting season. The content of the agricultural intensification section consisted of questions related to farmers' efforts to maintain farmland productivity by changing from labor-intensive farming to machine-intensive farming, changing the types of fertilizers and pesticides, and/or giving additional amounts of fertilizers/pesticides than had been used in the past. Further, we investigated whether they had specific methods to determine the starting point of the planting season and had made adjustments to these methods.

\section{Results}

This section summarizes farmers' perceptions of climate change impacts on their agricultural production based on questionnaire data collected from 152 respondents in the study area. The respondents' ages ranged between 34 and 65 years, with a mean value of 46 years. Most of the respondents had worked as farmers for more than two decades. The questionnaire also revealed that the socio-economic conditions of farmers in the study 
area tended to be homogeneous. The respondents became farmers because farming was a hereditary job passed from generation to generation. All of the respondents had a farmland holding less than 10 ha. Large-scale business farmers were uncommon in the study area since each farmer's household had their own farmland.

\subsection{Farmers' Perceptions of Climate Change Impacts}

Due to the fact that farmers' perceptions and forms of adaptation are mostly influenced by their farming environment [22], we investigated whether farmers who worked on irrigated farm areas had different perspectives to farmers who worked on dryland and orchard areas. Although all farmers concentrated on staple crops as the main cultivation plants, they had different types of farmland. Wetland farming focused on rice production, while dryland farming produced seasonal crops such as cassava, corn, or peanuts. Orchard farming had coconut trees as the main commodity. Table 2 shows that the majority of farmers (53\%) worked on wetland farms. No farmers solely worked in dry farming areas and only a small number (3\%) worked entirely in orchard areas. Some farmers had more than one type of farmland, namely wetland and dryland farming (35\%), wetland farming and orchards $(6 \%)$, or all three types $(3 \%)$. From this result, we can infer that differentiation of the farmland type can become a kind of adaptation, especially when there are large deficits of water that constrain the growth of wetland crops. This kind of adaptation could help the farmers when unpredictable climatic extremes occur.

Table 2. Type of respondents' farmland holding.

\begin{tabular}{cc}
\hline Type of Farmland & Percentage (\%) \\
\hline Wet land farming & 53 \\
Wet land and dry land farming & 35 \\
Wet land and orchard farming & 6 \\
Wet land, dry land, and orchard farming & 3 \\
Dry land farming & 0 \\
Orchard farming & 3 \\
\hline Total & 100 \\
\hline
\end{tabular}

Lack of water supplies could become a very serious problem, particularly for wetland farmers [9]. In the study area, water is the most important resource and tends to fluctuate widely within a single year. We therefore gave additional questions to wetland farmers in relation to water management on their farmland. The results exhibited a contradiction between the needs for and the availability of water. Although the majority of respondents were wetland farmers, only $32 \%$ had fully irrigated farmland (Table 3 ). The other $12 \%$ had semi-irrigated areas, which could only be irrigated when there was enough water, especially in the rainy season. Furthermore, more than half of the respondents (56\%) had rain-fed farming areas that were fully dependent on rain water availability. It was obvious that due to the large variance in precipitation between the rainy season and the dry season, only a small number of farmers (3\%) could grow and harvest rice three times a year. The rest ( $97 \%$ ) needed to adjust the crop planting pattern as a form of adaptation. In the rainy season, which generally starts in October and ends around April to May of the following year, farmers often grew two crops of rice. In the dry season (April-September), when soils became more arid, they substituted seasonal crops that require less water, such as cassava, corn and peanuts. 
Table 3. Types of respondents' wetland farming.

\begin{tabular}{cc}
\hline Type of Wet Land Farming & Percentage (\%) \\
\hline Irrigated & 32 \\
Half irrigated & 12 \\
Rain fed & 56 \\
\hline Total & 100 \\
\hline
\end{tabular}

The results also revealed different perceptions about climate change impacts on respondents' farmland, associated with increasing or decreasing temperature and precipitation. Only a small number of farmers (12\%) believed that higher amounts of precipitation had occurred. Almost half (41\%) thought that there had been no change in precipitation, while $26 \%$ of the farmers mentioned that precipitation had decreased (Table 4$)$. A fifth (21\%) of respondents were uncertain about the changes. We suspected that perspectives on the change in precipitation were possibly influenced by the farming location, which ranged from hilly to coastal areas. Therefore, climate change might have different impacts depending on the biogeophysical characteristics of each location [36]. Although there were vague answers in respect to changes in rainfall, perceptions about temperature changes yielded similar answers from almost all of the respondents. About $82 \%$ of them agreed that temperatures had increased, while $9 \%$ had noticed no change, and only $3 \%$ of them thought there was a decrease in temperature. Six percent were not sure about the change (Table 5). This means that even if there is no change in precipitation, the agricultural water balance will decrease due to higher evapotranspiration rates.

Table 4. Farmers' perception of rainfall change.

\begin{tabular}{cc}
\hline Farmer's Perception towards Rainfall Change & Percentage (\%) \\
\hline Increasing & 12 \\
Not changed at all & 41 \\
Decreasing & 26 \\
Not sure about the answer & 21 \\
\hline Total & 100 \\
\hline
\end{tabular}

Table 5. Farmers' perception of temperature change.

\begin{tabular}{cc}
\hline Farmer's Perception towards Temperature Change & Percentage (\%) \\
\hline Increasing & 82 \\
Not changed at all & 9 \\
Decreasing & 3 \\
Not sure about the answer & 6 \\
\hline Total & 100 \\
\hline
\end{tabular}

Climate change impacts on agriculture should not only be viewed in terms of an increase or decrease in specific climate variables over the long term. Even if there are no significant changes in the long term, climate change could result in the seasonal shift of key variables. For example, the rainy season could become shorter, while the dry season becomes longer, even though the annual precipitation remains same [12]. This change implies that a higher amount of rainfall occurs over a shorter time and could possibly become the main trigger of flood hazards [37,38]. The interviewers found evidence of a seasonal shift. Almost all the farmers (97\%) believed that the starting point of the planting season has become harder to predict owing to a shift in the rainy season, while only 3\% of the respondents believed that there was no change. It was common for farmers to use a traditional methodology to determine the beginning of rainy season, called "pranata mangsa" [39]. This system is part of the local wisdom acquired over generations based 
on the historical experiences of their ancestors. "Pranata mangsa" is a semiotic reading of natural signs in their environment, for example, observations of clear sky, browning leaves, and increasing spring discharges. In circumstances where the seasons changed regularly, this was considered reliable. However, it become less reliable in the recent years owing to increasing climate variability.

In this study, we also aimed to address the type of seasonal shift that occurred. It was obvious that climate variability has had an impact on seasonal shifts in the study area because all respondents stated that there were shifts in the onset of the rainy season. Some farmers (21\%) indicated that there was a delay in recent years, but the majority $(79 \%)$ thought that although there was a high probability of delayed onset, in some years the onset was earlier and, therefore, the change was quite erratic (Table 6). In addition to seasonal shifts, changes in the duration of the rainy season also should be taken into account. Here, the result was unclear (Table 7). About $42 \%$ of the respondents thought the rainy season duration had become shorter, while $12 \%$ stated the opposite. Fifteen percent believed that there was no change in the rainy season duration, while the remainder $(30 \%)$ mentioned that the duration varied from year to year, sometimes becoming shorter, sometimes longer.

Table 6. Farmers' perception of the rainy season onset.

\begin{tabular}{cc}
\hline Rainy Season Onset & Percentage (\%) \\
\hline Became delayed & 21 \\
Not changed & 0 \\
Became earlier & 0 \\
Became more erratic & 79 \\
Not sure about the change & 0 \\
\hline Total & 100 \\
\hline
\end{tabular}

Table 7. Farmers' perception of the rainy season duration.

\begin{tabular}{cc}
\hline Rainy Season Duration & Percentage (\%) \\
\hline Became shorter & 42 \\
Became longer & 12 \\
Not changed & 15 \\
Became more erratic & 30 \\
Not sure about the change & 0 \\
\hline Total & 100 \\
\hline
\end{tabular}

Changes in the patterns and amounts of temperature and precipitation are the main source of increasing magnitudes and frequencies of climate-change-induced hazards [25]. It is, therefore, possible that farmers have experienced such events and these have caused the crop failures mentioned in the previous section. Based on the questionnaire, 6\% of respondents often experienced floods, especially those who cultivated the lowland riverbanks. Fifteen percent of respondents cultivated rain-fed farms in the hills and often experienced droughts. About half (59\%) have suffered from both floods and droughts owing to their farm's location in the lowlands and the lack of irrigation channels. Only 20\% of the respondents had never encountered floods and droughts (Table 8). In association with current climate change issues and farmers' knowledge of climate change, we sought farmers' opinions in relation to factors that generated greater magnitude and intensity for hazards. Most of the farmers $(56 \%)$ believed that increasing hazard frequencies were purely natural, while $31 \%$ were not sure about the reason for the changing conditions. Only 13\% of respondents agreed that humans could possibly contribute to the changes (Table 9). 
Table 8. Impact of climate induced hazards on respondents' farmland.

\begin{tabular}{cc}
\hline Climate Induced Hazards Perceived & Percentage (\%) \\
\hline Increasing flood magnitude and frequency & 6 \\
Increasing drought magnitude and frequency & 15 \\
Both of flood and drought & 59 \\
Never & 20 \\
\hline Total & 100 \\
\hline
\end{tabular}

Table 9. Farmers' perception of human influence on change in climate characteristics.

\begin{tabular}{cc}
\hline Factors Influencing Change of Climate & Percentage (\%) \\
Characteristics & 56 \\
Purely natural factor & 13 \\
Humans can contribute & 31 \\
Not sure about the answer & 100 \\
\hline Total & \\
\hline
\end{tabular}

\subsection{Farmers' Perceptions of Climate Change Impacts}

The adaptation measures implemented by farmers represent straightforward responses to the actual problems facing them. The measures are often directly relevant to the scale of their farmland and emphasize agricultural diversification and intensification [17,18]. Socioeconomic adaptations are also often carried out by farmers to help stabilize their economic situation during unpredictable situations that result from climate variability. They are also important for securing and maintaining capital for the next season's production [18]. The types of climate change adaptation in the rural agricultural sector are profoundly different to urban areas. They are typical of developing countries where the local government becomes unresponsive, owing to a lack of knowledge about the future impacts of climate change [2]. Climate change mitigation in urban areas tends to be more responsive compared with rural areas due to larger potential economic losses. The local government in urban areas tends to have better resources and more capital for investment in mitigation, for example, by building dams and flood prevention infrastructure and reclamation of inundated areas [5].

Owing to the lack of response in addressing climate change impacts in the agriculture sector, it appears that the focal point for adaptation is the farmers themselves. However, farmers also have large difficulties in adapting to climate change without local government support. For example, the lack of infrastructure in the form of irrigation channels and very limited access to climate information and technology could increase exposure for farmers. In the study area, it was common for farmers in each village to establish a farmers' association to solve problems related to their farmland. Farmers' associations became places for sharing knowledge and information, as well as supporting each other by providing loans and increasing capacity building by working together to build irrigation channels from the nearby river. By setting up an association or group, farmers could easily access technical support from the local government.

From the results presented in Table 10, we observed that four types of agricultural diversification exist, consisting of: (1) changing plant varieties to ones that are more tolerant of climate variabilities; (2) replacing the crops with different entirely crops that are known to be more tolerant of high climate variability; (3) planting more than one type of crop within 1 year, but only one type for each planting season; and (4) planting more than one type of crops within one planting season. Almost all of the respondents substituted crops with a more tolerant variety. This was especially true in wetland farming, where farmers substituted a variety of rice that grew rapidly but required a lot of water, with another variety that had a slower growth rate but required less water. As mentioned in earlier sections, farmers in the study area also implemented a system of crop planting 
management to change the types of crop in each planting season within a year. In the context of wetland farming, most of the farmers grew and harvested rice twice a year and then planted seasonal crops, such as cassava and corn, in the dry season. This type of adaptation is not only carried out by wetland farmers, but also by dryland farmers. In the rainy season, they planted cassava and corn, while in the dry season they planted peanuts which require less water compared with other crops. This type of adaptation has several benefits in addition to minimizing climate risk, especially in avoiding land degradation from decreasing land fertility as a result of continuous cultivation. A smaller number of farmers entirely replaced their previous crops with new plant species to avoid the risk of absolute crop failure. This form of adaptation was mainly carried out by dryland farmers. The dryland farmers considered that this practice maximized their profit, which depends on price fluctuations. The results also indicated that less than half of the respondents cultivated more than one type of plant in one planting season.

Table 10. Forms of adaptation implemented by farmers.

\begin{tabular}{lcc}
\hline \multicolumn{1}{c}{ Forms of Adaptation } & Yes (\%) & No (\%) \\
\hline Crop diversification & 88 & 12 \\
Change to similar plant but different varieties that are more climate tolerant & 68 & 76 \\
Replace crops with entirely different crops & 48 & 24 \\
Plant more than one type of crops within one year & 94 & 52 \\
$\quad$ Plant more than one type of crops within one planting season & 30 & 70 \\
Crop intensification & 85 & 15 \\
Adjusting planting season & 79 & 21 \\
Utilize advanced machineries for farming & 83 \\
Give more fertilizer than usual & 79 \\
Give more pesticides than usual & & 17 \\
Social-capital adaptation & 21 \\
Has a side job in other sectors & \\
\hline
\end{tabular}

Out of a range of intensification efforts, including the use of advanced farming machinery, changing the type of fertilizers and pesticides, giving additional amounts of fertilizers and pesticides, and adjusting the planting season, most farmers tried to obtain more stable productivity by adjusting the planting time (94\%). In the study area, the farmers generally had three methods to decide the start of the planting phase, namely: (1) planting calendars (the most simple method conducted by using same date and month each year to determine the starting time for planting season), (2) "pranata mangsa" (a system of local wisdom learned by farmers in the study area), and (3) information from the Indonesian Bureau of Meteorology (BMKG) related to the beginning of the rainy season. Based on Table 11, it seems that the planting calendar that they used to use has become the least reliable at the current time, because of climate variability. Therefore, only $16 \%$ of respondents used this method. Most still used "pranata mangsa", which was considered more reliable. However, as stated previously, this method has also become less reliable. Some (10\%) have switched to more modern techniques based on the BMKG data. Several farmers also tried to combine these three methods to obtain a more reliable result.

Table 11. Information on the beginning of the rainy season as starting date for planting.

\begin{tabular}{cc}
\hline Information Related to the Beginning of Rainy Season & Percentage (\%) \\
\hline Indonesian Bureau of Meteorology (BMKG) & 10 \\
"Pranata mangsa" & 68 \\
Planting calendar & 16 \\
All of them & 6 \\
\hline Total & 100 \\
\hline
\end{tabular}


Intensification by adding more fertilizers and pesticides ranked second of the intensification practices. About $85 \%$ of respondents stated that they always added a higher volume of fertilizer to increase productivity. About $79 \%$ of respondents said that they used more pesticides because crops were more vulnerable to pests, especially grasshoppers and leafhoppers, and diseases, which have benefitted from changing climate conditions. Only $30 \%$ of respondents changed from labor-intensive farming to machinery-intensive farming. There are two main reasons why only a small number of the farmers preferred to invest in farming machinery. First, the initial cost of buying such machinery is very expensive, especially for small-scale farmers. Second, their farming area is often too small to be cultivated by machines.

Capital resources are very important to farmers in cultivating crops for the next planting season. Capital resources are also required to further invest in their farmland, for example, by buying more seeds, farming equipment, fertilizers and pesticides, or even farming machinery. Depletion of capital resources is unavoidable if crops fail because of extreme weather and climate variability. Farmers in the study area have developed several strategies to maintain capital resources. It was surprising that $83 \%$ had a second job outside agricultural sector. Most of the respondents worked as ranchers who breed chickens, goats, or cows. Some had second jobs as merchants in traditional markets, while the rest worked as construction laborers. When needed, most of them (79\%) also chose to obtain additional financial loans to recover from crop failures. This kind of adaptation was supported by the existence of farmers' associations that loaned money and allowed farmers to ensure the continuity of their farming activities.

\section{Discussion}

Identifying the farmers' perspectives in respect to climate change impacts in agriculture as well as their adaptation measures has several advantages. Farmers' perceptions can be used as a source of information to compare with climate data observation [22,24]. In the study area, there was a change in climate variables, mainly precipitation and temperature, which was also sensed by farmers. Although the amount of precipitation has only slightly changed annually, recently there have been large seasonal differences compared with the past. Based on the climate observation data, precipitation has been lower in the rainy season but higher in the dry season. This was confusing for farmers as some of them thought that there had been a decrease in rainfall due to the lack of precipitation in the rainy season. It also indicated a higher variability in precipitation and seasonal shifts, so farmers were not sure whether rain was decreasing, increasing, or the same as in the past. Temperature, as observed from climate observation data, showed a continuous increase from year to year. This was noticed by most farmers and the majority stated that the temperature was continuously increasing.

The interviews revealed the potential impact of climate change on paddy field farmers in the region. Currently, an increasing flood and drought magnitude and frequency had already been experienced by the farmers. The observational climate data informed us that farmers were affected in the form of increasing temperature and shifting of precipitation patterns. This condition remains challenging due to projected increases in temperature for at least the next 100 years [40]. However, only $13 \%$ of farmers believed that human activity had contributed to the current climate. This percentage is lower than similar studies [24]. Even at the global scale, knowledge related to climate change and human influence remains low for farmers. This result shows that there are missing links between knowledge at the governmental level and its implementation at the farm level [26].

Decreases in agricultural productivity due to climate change and climate variability have been identified in many parts of Indonesia. For example, the suitability of paddy fields has decreased by $20 \%$ in the last two decades on the island of Bali [41]. In the Lampung region, the southernmost part of the island of Sumatra, there has been a decline in the productivity of food crops, especially cassava [42]. The above condition has an impact on the decline in food security at the provincial level. In Central Sulawesi, the impact of 
drought on rice crops is increasing, especially during El Nino events [43]. Therefore, it can be inferred that decreasing rainfall and increasing temperature will be the main problems faced by farmers in Indonesia in the future.

Most of the adaptation efforts made by smallholder farmers are limited to reactive adaptation-for example, accessing loans when there is crop failure [43]. Local governments have responded to this by providing microfinance and agricultural insurance [44]. In addition, adaptation in the form of social capital was also identified in Yogyakarta (the central part of Java) [45]. In this area, farmers contribute financially to solve problems related to climate and water resources. The involvement of farmers is mainly in the construction of irrigation networks, water storage, and pest control. Meanwhile, the most frequent individual adaptation effort is the application of fertilizers to increase productivity [41].

\section{Conclusions}

The above results suggest that there is a gap in the policy and implementation of climate change mitigation and adaptation from the national level, local government, and community in the study area. A sound understanding of climate change impacts is even more important for farmers when combined with land degradation and farm mismanagement, as this could increase exposure to climate change. At present, several adaptation measures have been implemented by local farmers, mainly through crop diversification, crop intensification, and socioeconomic adaptation. However, these forms of adaptation are still limited due to lack of resources, capital, and knowledge of their ability to adjust to current and future climate conditions. Therefore, the policy makers from the national to local level need robust mitigation and adaptation measures that are applicable for local communities, particularly to increase the farmers' resilience to climate change.

Farmers' perceptions could inform the potential climate change impacts in the future of Indonesian agriculture sector. However, the perceptions of changes in climate variables were not always in line with the empirical climatology data. This was possibly derived from several factors, including personal and social experience, and also environmental factors. The farmer's experience, particularly how long they have been a farmer, could affect their perception. Social interaction with the farmer association also could influence their perceptions by highlighting specific environmental issues that affect their farmlands. Environment factors could influence farmers because each location has specific environmental characteristics that produce different responses to climate change [30]. This condition also depends on the type of climate variables producing strong impacts (i.e., precipitation and temperature) and the temporal scale of the change (annual/seasonal).

In determining the planting period, most of today's farmers (68\%) still use traditional methods. The above results showed that farmers' access to information and technology regarding climate is still limited. The Indonesian government (through the Department of Agriculture) seeks to encourage modernization in determining and adjusting the planting calendar, mainly based on the BMKG predictions. Dissemination of information at the beginning of the planting period is currently mostly provided through farmer groups as coordinators in their respective areas. Through more accurate information on early rainy season data, farmers can better prepare for the planting season, thereby reducing the risk of crop failure.

The large percentage of farmers who access loans to continue agricultural activities in the next growing season can continue to be a severe problem. Economic losses faced by farmers due to crop failure can significantly affect the economy of farming households. Farmers need guarantees for the commodities that have been planted. One of the current efforts of the Indonesian government is to protect the farmers' economy by providing a farming insurance program at the national level. If farmers experience crop failure due to climate uncertainty and variability, farmers are entitled to compensation.

Although the government of Indonesia has made several efforts to support farmers' adaptation to climate change, for example, by modernizing the planting calendar and agricultural insurance programs, their effectiveness in strengthening farmer resilience still 
needs attention. The increase in hydrometeorological disasters triggered by climate change is currently increasing from year to year. Regardless of appropriate cropping patterns, disaster events often result in significant losses to the agricultural sector. Thus, the above efforts need to be supported by infrastructure development and environmental conservation.

Author Contributions: Conceptualization, A.B.S. and E.N.; methodology, A.B.S.; validation, F.N.; formal analysis, E.N.; investigation, A.B.S.; resources, F.N.; writing-original draft preparation, A.B.S.; visualization, F.N.; supervision, E.N.; project administration, E.N.; funding acquisition, E.N. All authors have read and agreed to the published version of the manuscript.

Funding: This research was funded by Grant of "Prioritas Riset Nasional—SIMLITABMAS" from Indonesian Ministry of Education and Culture in 2021 with Dr. Emilya Nurjani as the principal investigator (Contract number: 1736/UN1/DITLIT/DIT-LIT/2021).

Institutional Review Board Statement: Not applicable.

Informed Consent Statement: Not applicable.

Data Availability Statement: Restrictions apply to the availability of the meteorological data. The meteorological data was obtained from Indonesian Bureau of Meteorology (BMKG) Central Java regional office and are available by request to BMKG Office Semarang (http:/ / www.iklimjateng. info/). The interview data presented in this study are available on request from the corresponding author. The data are not publicly available due to Terms and Condition agreed by the interviewer and interviewee regarding to publication of interview results.

Conflicts of Interest: The authors declare no conflict of interest.

\section{References}

1. Intergovernmental Panel on Climate Change (IPCC). Climate Change 2001: Impacts, Adaptation, and Vulnerability. Contribution of Working Group II to the Third Assessment Report of the Intergovernmental Panel on Climate Change; McCarthy, J.J., Canziani, O.F., Leary, N.A., Dokken, D.J., White, K.S., Eds.; Cambridge University Press: Cambridge, UK, 2001.

2. Marfai, M.A.; Sekaranom, A.B.; Ward, P. Community Responses and Adaptation Strategies toward Flood Hazard in Jakarta, Indonesia. Nat. Hazards 2015, 75, 1127-1144. [CrossRef]

3. Sivakumar, M.V.K. Impacts of Natural Disasters in Agriculture, Rangeland and Forestry: An Overview. In Natural Disasters and Extreme Events in Agriculture; Springer: Berlin/Heidelberg, Germany, 2005; pp. 1-22.

4. Kobayashi, H. Vulnerability Assessment and Adaptation Strategy to Sea-Level Rise in Indonesian Coastal Urban Areas; National Institute for Land and Infrastructure Management: Tsukuba, Japan, 2003.

5. Marfai, M.A.; King, L. Potential Vulnerability Implications of Coastal Inundation Due to Sea Level Rise for the Coastal Zone of Semarang City, Indonesia. Environ. Geol. 2008, 54, 1235-1245. [CrossRef]

6. Marfai, M.A. Impact of Sea Level Rise to Coastal Ecology: A Case Study on the Northern Part of Java Island, Indonesia. Quaest. Geogr. 2014, 33, 107-114. [CrossRef]

7. Deschênes, O.; Greenstone, M. The Economic Impacts of Climate Change: Evidence from Agricultural Output and Random Fluctuations in Weather. Am. Econ. Rev. 2007, 97, 354-385. [CrossRef]

8. Indonesian Bureau of Statistics. Population Census of Indonesia 2010; Indonesian Bureau of Statistics: Jakarta, Indonesian, 2010.

9. Lei, Y.; Wang, J.; Luo, L. Drought Risk Assessment of China's Mid-Season Paddy. Int. J. Disaster Risk Sci. 2011, 2, 32-40. [CrossRef]

10. Sekaranom, A.B.; Suarma, U.; Nurjani, E. Climate Extremes over the Maritime Continent and Their Associations with MaddenJullian Oscillation. IOP Conf. Ser. Earth Environ. Sci. 2020, 451, 12006. [CrossRef]

11. Sekaranom, A.B.; Nurjani, E.; Harini, R.; Muttaqin, A.S. Simulation of Daily Rainfall Data Using Articulated Weather Generator Model for Seasonal Prediction of ENSO-Affected Zones in Indonesia. Indones. J. Geogr. 2020, 52, 143-153. [CrossRef]

12. Bates, B.; Kundzewicz, Z.; Wu, S. Climate Change and Water; Intergovernmental Panel on Climate Change Secretariat: Geneva, Switzerland, 2008.

13. Naylor, R.L.; Battisti, D.S.; Vimont, D.J.; Falcon, W.P.; Burke, M.B. Assessing Risks of Climate Variability and Climate Change for Indonesian Rice Agriculture. Proc. Natl. Acad. Sci. USA 2007, 104, 7752-7757. [CrossRef]

14. Motha, R.P.; Baier, W. Impacts of Present and Future Climate Change and Climate Variability on Agriculture in the Temperate Regions: North America. Clim. Chang. 2005, 70, 137-164. [CrossRef]

15. Lal, M. Implications of Climate Change in Sustained Agricultural Productivity in South Asia. Reg. Environ. Chang. 2011, 11, 79-94. [CrossRef]

16. Kotir, J.H. Climate Change and Variability in Sub-Saharan Africa: A Review of Current and Future Trends and Impacts on Agriculture and Food Security. Environ. Dev. Sustain. 2011, 13, 587-605. [CrossRef]

17. Maja, M.M.; Ayano, S.F. The Impact of Population Growth on Natural Resources and Farmers' Capacity to Adapt to Climate Change in Low-Income Countries. Earth Syst. Environ. 2021, 1-13. [CrossRef] 
18. Brown, P.R.; Afroz, S.; Chialue, L.; Chiranjeevi, T.; El, S.; Grünbühel, C.M.; Khan, I.; Pitkin, C.; Reddy, V.R.; Roth, C.H.; et al. Constraints to the Capacity of Smallholder Farming Households to Adapt to Climate Change in South Africa and Southeast Asia. Clim. Dev. 2019, 11, 383-400. [CrossRef]

19. Islam, M.S.; Kieu, E. Tackling Regional Climate Change Impacts and Food Security Issues: A Critical Analysis across ASEAN, PIF and SAARC. Sustainability 2020, 12, 883. [CrossRef]

20. USAID. Indonesia: Costs of Climate Change 2050; USAID: Washington, DC, USA, 2016.

21. Gebrehiwot, T.; Van Der Veen, A. Farm Level Adaptation to Climate Change: The Case of Farmer's in the Ethiopian Highlands. Environ. Manag. 2013, 52, 29-44. [CrossRef] [PubMed]

22. Yaro, J.A. The Perception of and Adaptation to Climate Variability/Change in Ghana by Small-Scale and Commercial Farmers. Reg. Environ. Chang. 2013, 13, 1259-1272. [CrossRef]

23. Adger, W.N.; Agrawal, S.; Mirza, M.M.W.; Conde, C.; O’brien, K.L.; Pulhin, J.; Pulwarty, R.; Smit, B.; Takahashi, K. Assessment of Adaptation Practices, Options, Constraints and Capacity. In Climate Change 2007: Impacts, Adaptation and Vulnerability. Contribution of Working Group II to the Fourth Assessment Report of the Intergovernmental Panel on Climate Change; Cambridge University Press: Cambridge, UK, 2007.

24. Sima, M.; Popovici, E.-A.; Bălteanu, D.; Micu, D.M.; Kucsicsa, G.; Dragotă, C.; Grigorescu, I. A Farmer-Based Analysis of Climate Change Adaptation Options of Agriculture in the Bărăgan Plain, Romania. Earth Perspect. 2015, 2, 5. [CrossRef]

25. Field, C.B.; Barros, V.; Stocker, T.F.; Dahe, Q. Managing the Risks of Extreme Events and Disasters to Advance Climate Change Adaptation: Special Report of the Intergovernmental Panel on Climate Change; Cambridge University Press: Cambridge, UK, 2012.

26. Liu, Z.; Smith, W.J.; Safi, A.S. Rancher and Farmer Perceptions of Climate Change in Nevada, USA. Clim. Chang. 2014, 122, 313-327. [CrossRef]

27. Kumalasari, N.R.; Bergmeier, E. Effects of Surrounding Crop and Semi-Natural Vegetation on the Plant Diversity of Paddy Fields. Agric. Food Secur. 2014, 3, 1-8. [CrossRef]

28. Abraham, B.; Araya, H.; Berhe, T.; Edwards, S.; Gujja, B.; Khadka, R.B.; Koma, Y.S.; Sen, D.; Sharif, A.; Styger, E.; et al. The System of Crop Intensification: Reports from the Field on Improving Agricultural Production, Food Security, and Resilience to Climate Change for Multiple Crops. Agric. Food Secur. 2014, 3, 1-12. [CrossRef]

29. Falcon, W.P.; Naylor, R.L.; Smith, W.L.; Burke, M.B.; McCullough, E.B. Using Climate Models to Improve Indonesian Food Security. Bull. Indones. Econ. Stud. 2004, 40,355-377. [CrossRef]

30. Indonesian Bureau of Statistics. Kebumen in Figures 2013; Indonesian Bureau of Statistics: Jakarta, Indonesian, 2013.

31. Marfai, M.A.; King, L.; Singh, L.P.; Mardiatno, D.; Sartohadi, J.; Hadmoko, D.S.; Dewi, A. Natural Hazards in Central Java Province, Indonesia: An Overview. Environ. Geol. 2008, 56, 335-351. [CrossRef]

32. Black, P.E. Revisiting the Thornthwaite and Mather Water Balance 1. JAWRA J. Am. Water Resour. Assoc. 2007, 43, 1604-1605. [CrossRef]

33. Rakhecha, P.; Singh, V.P. Applied Hydrometeorology; Springer Science \& Business Media: New York, NY, USA, 2009.

34. Norris, P.E.; Batie, S.S. Virginia Farmers'soil Conservation Decisions: An Application of Tobit Analysis. South. J. Agric. Econ. 1987, 19, 79-90.

35. Pryanishnikov, I.; Zigova, K. Multinomial Logit Models for the Austrian Labor Market. Austrian J. Stat. 2003, 32, $267-282$. [CrossRef]

36. Del Barrio, G.; Harrison, P.A.; Berry, P.M.; Butt, N.; Sanjuan, M.E.; Pearson, R.G.; Dawson, T. Integrating Multiple Modelling Approaches to Predict the Potential Impacts of Climate Change on Species' Distributions in Contrasting Regions: Comparison and Implications for Policy. Environ. Sci. Policy 2006, 9, 129-147. [CrossRef]

37. Sekaranom, A.B.; Nurjani, E.; Pujiastuti, I. Cloud Structure Evolution of Heavy Rain Events from the East-West Pacific Ocean: A Combined Global Observation Analysis. IOP Conf. Ser. Earth Environ. Sci. 2018, 148, 12006. [CrossRef]

38. Guhathakurta, P.; Sreejith, O.P.; Menon, P.A. Impact of Climate Change on Extreme Rainfall Events and Flood Risk in India. J. Earth Syst. Sci. 2011, 120, 359-373. [CrossRef]

39. Daldjoeni, N. Pranatamangsa, the Javanese Agricultural Calendar-Its Bioclimatological and Sociocultural Function in Developing Rural Life. Environmentalist 1984, 4, 15-18.

40. Elguindi, N.; Grundstein, A.; Bernardes, S.; Turuncoglu, U.; Feddema, J. Assessment of CMIP5 Global Model Simulations and Climate Change Projections for the 21st Century Using a Modified Thornthwaite Climate Classification. Clim. Chang. 2014, 122, 523-538. [CrossRef]

41. Takama, T.; Setyani, P.; Aldrian, E. Climate Change Vulnerability to Rice Paddy Production in Bali, Indonesia. In Handbook of Climate Change Adaptation; Springer: Berlin/Heidelberg, Germany, 2014; pp. 1-23.

42. Murniati, K.; Widjaya, S.; Rabiatul, A.; Listiana, I. Climate Change Adaptation Strategy for Sustainability and Food Security of Cassava Farming Households in Lampung, Indonesia. J. Agric. Ext. 2019, 23, 138-146. [CrossRef]

43. Keil, A.; Zeller, M.; Wida, A.; Sanim, B.; Birner, R. What Determines Farmers' Resilience towards ENSO-Related Drought? An Empirical Assessment in Central Sulawesi, Indonesia. Clim. Chang. 2008, 86, 291-307. [CrossRef]

44. Budiman, I.; Takama, T.; Pratiwi, L.; Soeprastowo, E. Role of Microfinance to Support Agricultural Climate Change Adaptations in Indonesia. Future. Food J. Food Agric. Soc. 2016, 4, 55-68.

45. Saptutyningsih, E.; Diswandi, D.; Jaung, W. Does Social Capital Matter in Climate Change Adaptation? A Lesson from Agricultural Sector in Yogyakarta, Indonesia. Land Use Policy 2020, 95, 104189. 